\title{
Conviction rates of alleged rape offenders from 2006-2016: A special reference to false rape charges in NCT Delhi
}

\author{
Aakash Sethi ${ }^{1}$, Mukesh Yadav ${ }^{2}$, Akhilesh Pathak $^{3}$, Kalpita Shringarpure ${ }^{4}$ \\ ${ }^{1}$ 3rd MBBS student, Government Medical College Baroda, Gujarat. \\ ${ }^{2}$ Professor, Department of Forensic Medicine and Toxicology, Principal, Government Allopathic \\ Medical College, Banda, U.P. \\ ${ }^{3}$ Professor and Head, Department of Forensic Medicine and Toxicology, All India Institute of \\ Medical Sciences, Bathinda Punjab. \\ ${ }^{4}$ Tutor, Department of Preventive and Social Medicine, Government Medical College, Baroda.
}

Corresponding Author: Aakash Sethi

E-mail: sethiaakash22@gmail.com

\begin{abstract}
Background: Reported rape incidents in India are increasing each year. The present study was undertaken to analyse the conviction rate of the alleged rape offenders in the whole of India. It also reviewed the Delhi High Court judgements with respect to alleged rape offences.

Methodology: This is a retrospective record review of data from the websites of Delhi High Court and the National Crime Record Bureau between January \& December 2017. The data having the keyword 'rape' in judgements given by the court during the year 2017 were included in the analysis. The false rape cases included cases in which the court found that the women had accused the person of committing rape but actually rape had not been committed.

Results: In 2017, there were 51 judgements with the word 'rape'. In 13 cases, the word 'rape' appeared for reasons other than the actual 'rape' instance, while the rest 38 cases were actual rape offences. The accused was acquitted of rape charges in 24 cases; of which 21 cases were false charges of rape.

Conclusion: The present study shows that the rate of acquittal in alleged rape cases is very high in India; either due to the false allegations of rape charges or lack of evidence to prove it beyond reasonable doubt. We were able to find out ulterior motives of the victims, which led her to falsely accuse a man of a heinous crime such as rape.
\end{abstract}

Keywords: Rape, False Rape crimes, Delhi rape incident, Section 376 IPC

\section{Introduction}

Rape is legally defined under the Section 375 of I.P.C. and the punishment for Rape, Gang rape and rape under custody is defined under S 376 IPC and its subsections [1]. A major amendment in the rape laws took place in 2013 after the infamous Nirbhaya Rape case which shook the whole of India [2]. The previous rape laws differed as compared to the current rape laws in terms of age of consent being 16 years, penetration of any object inside the women's mouth, urethra, anus, and vagina now constituted as rape, medical examination being made an exception, consent being 
defined, Punishment under Section 376 was increased with highest punishment being Hanging to death in some (e.g. - Repeat offence, Sexual Assault that leaves women in a permanent vegetative state, Gang Rape).

As per news reports, the conviction rate of rape cases has been abysmally low [3]. In the aftermath of the Mathura Custodial Rape case of 1972, an important law related to rape was enacted namely 'The Criminal Law Amendment Act, 1983'. It introduced the Section 114A in the Indian Evidence Act (IEA), 1872. As per this section, where sexual intercourse by the accused is proved and the question is whether or not consent had been given by the woman; and she states in her evidence before the Court that she did not consent, the Court shall presume that she did not consent. In the year 2018, rape was the fourth highest commonly reported crime against women after Cruelty by husband (Sec. 498 A IPC), Assault on Women with Intent to Outrage her Modesty (Sec. 354 IPC) and Kidnapping [4].

A study to assess the conviction rates was done in India in which the court judgements were analyzed and judges interviewed [5]. Our study additionally analyzes the National Crime Records Bureau (NCRB) Crimes in India report over the past decade (2006-2016) as well Delhi High Court judgments on rape cases. The specific reason that Delhi was selected is due to the reasons of Court judgements being easily available from an official source (Delhi High Court website) and Delhi is infamously called the rape capital of India because of the rising cases over the years [6].

The NCRB releases its publication "Crimes in India" annually. It lists the statistics related to various crimes collected over each year. As per the 2016 reports, Delhi was ranked number one in both the number of rapes as compared to metropolitan cities as well as crimes against women as compared to whole of India [6], hence it is also infamously called as the rape capital of India. Hence, this study was conducted to evaluate the reasons for rising reported rape incidents, trend of Conviction rate of Rape cases over the years and to note the instances wherein a man is falsely accused of rape. Conviction rate of crime is defined as number of cases where the accused was convicted divided by the total number of cases that were disposed of by the courts [6]. Prosecutrix is a woman who brings a charge against someone in a court of law [7]. In this case it would the rape survivor. Precedent is a decided case that furnishes a basis for determining later cases involving similar facts or issues [8].

The aim of the study was to analyze the Conviction rates of alleged rape offenders from years 2006-2016 and analytically review the Judgements given by Delhi High court in rape case. The objectives were -

a. To represent trend of the conviction rate, reported cases, pendency percentage of Rape cases

b. To determine if there are any rape allegations which are false

c. Determine the Relative evidentiary value of the testimony of the prosecutrix as opposed to Other corroborative evidence

\section{Methodology}

The study was conducted in Government Medical College Baroda, Gujarat from $1^{\text {st }}$ June to $31^{\text {st }}$ June 2019. This was an observational cross Sectional study based on record review.

The data collection was from the following two sources -

a) To find the court judgments related to rape offences the websitehttp://delhihighcourt.nic.in/freetextsearch.asp was used to find relevant court was found and were analyzed. After going through all the 51 Judgements, we sorted out the cases in which False Rape charges were made. The false rape charges included the cases in which there was element of falseness in the case either because the rape charges had been added to increase the punishment levied by the court, due to some other personal problem with the accused or when the relatives of the victim found out about the consensual relation of the victim with the accused.

b) Data related to crime and conviction rate was taken from the National Crime record bureau website - http://ncrb.gov.in/ . The annual statistical publication named "Crimes in India" from the years 2006 to 2016 was used to gather data. 
The following parameters are for the 'Data source 1'

Inclusion criteria

- The court judgements from $01 / 01 / 2017$ to $01 / 01 / 2018$

- Judgement contained the keyword 'rape'

Exclusion criteria: Cases where the term 'rape' had appeared but the charges were not of rape The sampling method used was convenience sampling.

\section{Variables -}

- Qualitative - Sex of the Judge, False case or not, Reason for being false, arguments used by defense lawyer, whether or not the accused knew each other or not, whether or not reliance was placed on medical evidence

- Quantitative - Age of Female, length of the judgement

Data Collection and Analysis: Data was entered in and analyzed using Microsoft Excel. Qualitative data is expressed using percentage

\section{Results}

\section{Crimes in India (2006-2016)}

There was an increase in the number of reported rape cases over the decade with 19348 cases in 2006, 24206 in 2011, which almost doubled after 10 years 38946 in 2016. (Table 1, figure 1 and 2) For the rape cases in $2016(n=38946)$, charge sheet was submitted by police in $88 \%(33628)$ of cases. For the remaining cases they either found them to be False $(2839,7 \%)$, True but insufficient evidence $(1474,4 \%)$, Mistake of Fact $(249,0.63 \%)$ or Non Cognizable $(66,0.17 \%)$ (Figure 3)

\begin{tabular}{|c|c|c|c|c|c|}
\hline Year & $\begin{array}{l}\text { Crimes against } \\
\text { women }\end{array}$ & $\begin{array}{l}\text { Rape case } \\
\text { Reported }\end{array}$ & $\begin{array}{l}\text { Rape as a \% of crimes against } \\
\text { women }\end{array}$ & $\begin{array}{l}\text { Rape as a \% to } \\
\text { total IPC crimes }\end{array}$ & $\begin{array}{l}\text { Conviction } \\
\text { rate* }(\%)\end{array}$ \\
\hline 2006 & 164765 & 19,348 & 11.74 & 1 & 27.2 \\
\hline 2007 & 185312 & 20,737 & 11.19 & 1 & 26.4 \\
\hline 2008 & 195865 & 21,467 & 10.96 & 1 & 26.6 \\
\hline 2009 & 203804 & 21,397 & 10.50 & 1 & 26.9 \\
\hline 2010 & 213585 & 22,172 & 10.38 & 1 & 26.6 \\
\hline 2011 & 228650 & 24,206 & 10.59 & 1 & 26.4 \\
\hline 2012 & 244270 & 24,923 & 10.20 & 1 & 24 \\
\hline 2013 & 309546 & 33,707 & 10.89 & 1.3 & 27.1 \\
\hline 2014 & 337922 & 36,735 & 10.87 & 1.3 & 28 \\
\hline 2015 & 327394 & 34,651 & 10.58 & 1.2 & 29.4 \\
\hline 2016 & $3,38,954$ & 38,947 & 11.49 & 1.3 & 25.5 \\
\hline
\end{tabular}

\section{Judgement analysis}

As per the classification of Delhi High court Cases (2017), 51 cases had the term rape. However 38 judgements out of these were actually related to rape; of whom court rejected bail or held the 
accused guilty of rape in 14 cases. In 21 out of 24 cases where the accused was acquitted, the case was that of a false rape charge case (Figure 4).
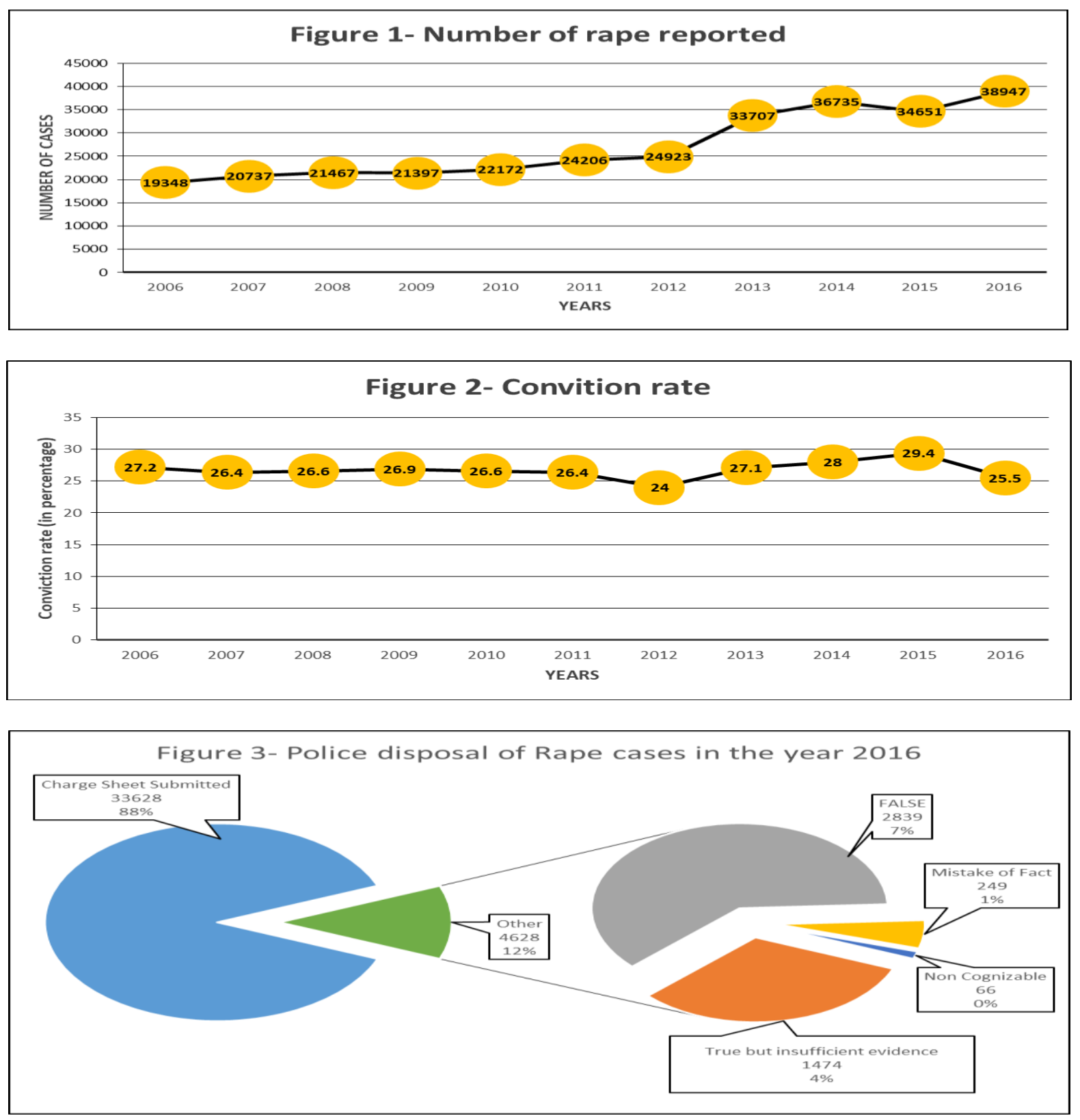

In the 25 rape cases $(65.7 \%)$ the age of the victim was mentioned. The mean (SD) age of the victim was 18.6 (7.4) years with maximum age of 33 and minimum age of four years. In 5 cases $(20 \%)$ the female was aged between 18 and 30years and in 17 cases $(68 \%)$, the female was a minor. As compared to 2017, rape Crimes data, $50.2 \%$ of females were aged between 18 and 30 and $30.3 \%$ were minor (Table 3)

All judgments were written in English. Occasionally, some Hindi words were used to express the original verbatim words of the victim. The length of the judgments differed substantially. The shortest judgment was of four pages and the longest judgement was of 26 pages. The judgement in the actual rape cases $(n=38)$, was delivered by a male judge in $58 \%$ cases, $37 \%$ were female judge in $37 \%$ cases. In the remaining 2 cases, judgement was delivered by a two judges bench (also called a division bench) which comprised of a male and female judge in one case (2.6\%) and two female judges in the other $(2.6 \%)$. 
Out of the 21 cases which were false rape allegations, 13 cases had the female as a consenting party, while in 8 cases, there were major Discrepancies in statements made by victim. All the reasons with their relative frequency is given in Table 2.

In the actual cases of rape $(n=38), 64 \%$ were appeals against a lower court judgement. Most of these appeals were made by the convict $(27,51 \%)$. The rape victim went into appeal against appeal in only $6 \%$ of cases (3). The rest of appeals against acquittal was made by the State (4,7\%) (Figure 5). Out of the 38 actual judgements related to rape offences, in $55.2 \%$ (21) cases the accused was known to the Victim. Comparing this with the 2017 rape crime data, in $93.05 \%$ cases, was the accused known to the victim

\begin{tabular}{|l|l|}
\hline \multicolumn{2}{|c|}{ Table 2- The reasons for being false } \\
\hline Reason considered for being false & Frequency \\
\hline Consenting party & 13 \\
\hline Major Discrepancies in statements made by victim & 8 \\
\hline Case Modified to include rape due to personal enmity & 6 \\
\hline $\begin{array}{l}\text { The claim that false pretext of marriage was done to obtain consent was } \\
\text { deemed wrong }\end{array}$ & 2 \\
\hline Insufficient evidence & 1 \\
\hline
\end{tabular}

\begin{tabular}{|l|l|l|}
\hline \multicolumn{2}{|c|}{ Table 3- Comparison between judgement analysis and NCRB report } \\
\hline Parameter & My results & NCRB report (2017) \\
\hline Accused was known to the victim & $21 / 38(55.2 \%)$ & $30299 / 32559(93.05 \%)$ \\
\hline $\begin{array}{l}\text { Rape committed against females } \\
\text { aged 18 to 30 years }\end{array}$ & $5 / 25(20 \%)$ & $16900 / 33658(50.2 \%)$ \\
\hline $\begin{array}{l}\text { Rape committed against females } \\
\text { aged less than 18 years }\end{array}$ & $17 / 25(68 \%)$ & $10221 / 33658(30.3 \%)$ \\
\hline
\end{tabular}

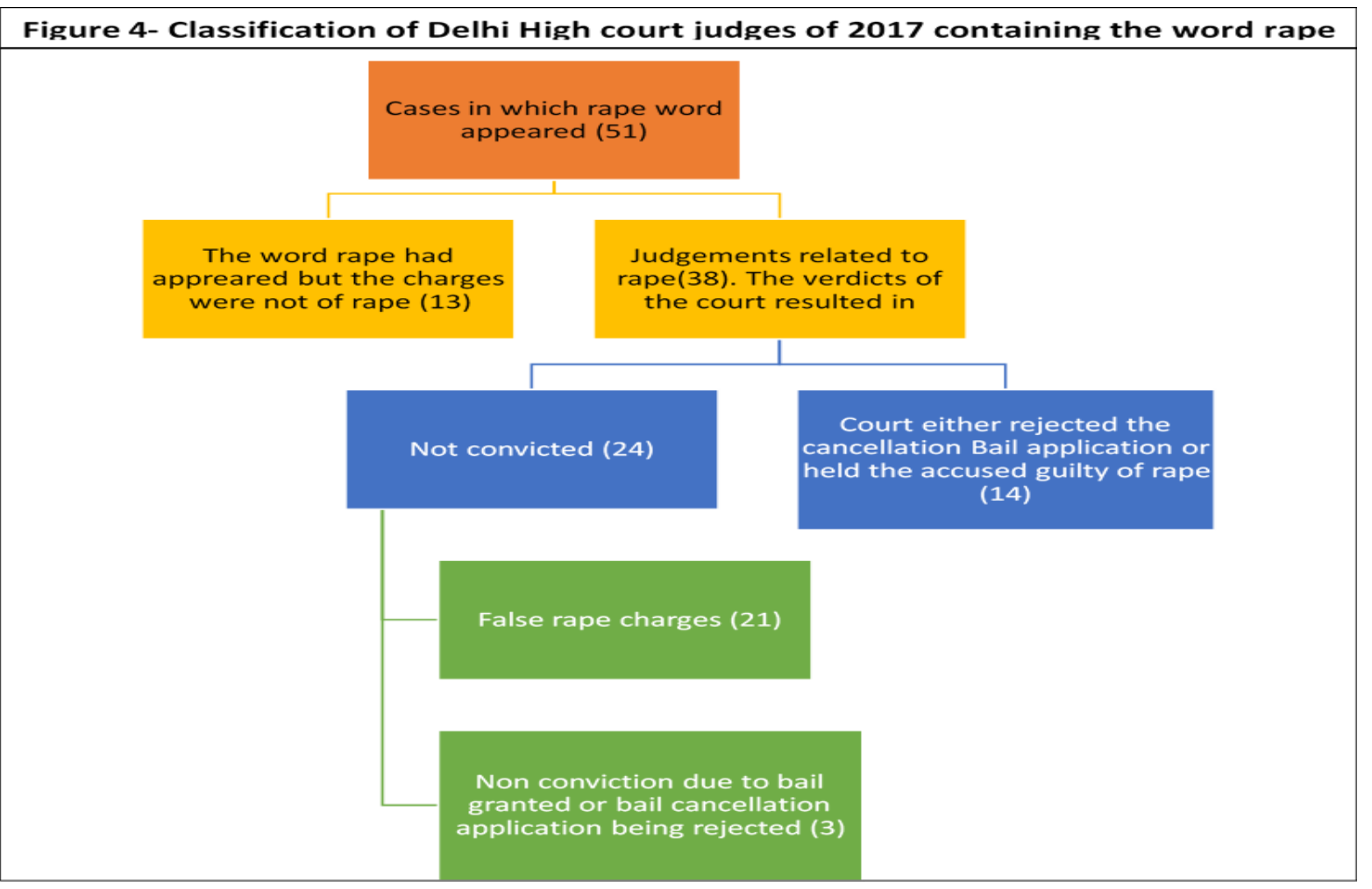




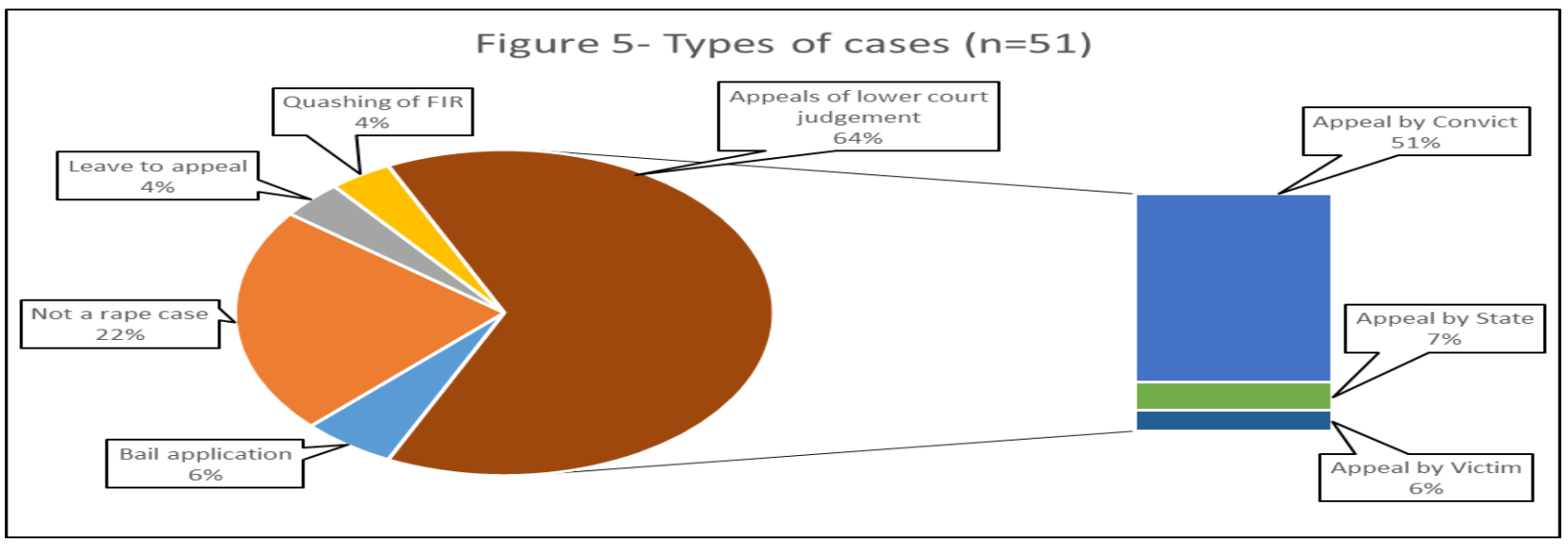

\section{Discussion}

This paper is set out to explore the domain of false rape cases and the conviction rate in rape cases. A key contribution of this article is that it explores a relatively under researched area of Trends in conviction rate, reported cases, pendency percentage of Rape cases. Rape cases have been increasing over the few years. In order to verify this trend, this study was conducted over a period of 2006-2016. In addition to the study earlier conducted [5], this study compared the data from the Delhi Court Judgement and the NCRB data.

This study notes an increase in the rape cases over the years. This can not only be attributed to increasing numbers of rape being committed but also due to criminalization of non-penetrative assaults like forceful oral sex. After 2013, the Criminal Law (Amendment) Act, 2013 also known as the Nirbhaya Act, widened the scope of Rape as defined under Sec. 375 IPC (2). A notable spike in number of cases can be seen in year 2014 (Figure 5) and it could be possibly due to public outrage over the issue of rape and the acceptance of the victims of sexual offences. This would have encouraged females to increasingly report the crimes that were previously not being done. As about eight out of ten of the rape cases in India were earlier not reported [9-11] there are chances that increased reporting of cases could be responsible for the rising number of rape cases reported. Yet, the conviction rate remained more or less stable with it being $27.2 \%$ in 2006 and 25.5 in 2016.

Comparing with the previous study [5], this study also contained maximum appeals in High courts by the convicts (Figure 2). Similar to the view expressed by the judges who were interviewed in the study. The High Court quoted the precedents laid down by Supreme Court regarding the sole testimony of the prosecutrix being directly considered without appropriate corroboration by the evidence. From the quoted Supreme Court judgements, it can be said that if vital discrepancies and not just minor inconsistencies had arisen in the statement given by prosecutrix, then the court needs to look into the medical evidence for corroboration. It was when the evidence placed on record did not back the statement made by the women and witnesses, the court gave the accused the benefit of doubt and acquitted him.

Some of the landmark judgements of the Supreme Court on the matter of 'Testimony of the prosecutrix' have been reproduced here. In Abbas Ahmed Choudhury v. State of Assam [12], the Supreme Court observed that a case of sexual assault has to be proved beyond reasonable doubt as any other case and that there is no presumption that a prosecutrix would always tell the entire story truthfully

In Sadashiv Ramrao Hadbe vs. State of Maharashtra \& Anr [13], the Apex Court while reiterating that in a rape case, the accused could be convicted on the sole testimony of the prosecutrix if it is capable of inspiring the confidence in the mind of the Court, put a word of caution that the Court should be extremely careful while accepting the testimony when the entire case is improbable and unlikely to have happened. This is what has been stated:

In a judgement entitled Shiv Pujan @ Shubh Karan Vs The State (NCT of Delhi) [14] the Delhi High court stated that vital discrepancies and infirmities have emerged in the statement of the prosecution witnesses. It therefore proceeded to corroborate statement of the women with the evidence. 
A study in which judges were interviewed on the matter of cases of sexual assault [5] one of the judges said he found "It is unimaginable that a young girl in Indian society would concoct an untruthful story and level charges of rape for the purposes of blackmail, animosity or revenge". A key finding from the study was that the position of the judges reflects a belief that victim must be genuine because the associated shame and stigma is so powerful that it obviates false reports.

The Judges place reliance on corroborative medical evidence in the establishment of charges of rape against the accused. In the earlier study done [5], in ten cases medical evidence being non reliable was noted. However, in this study, no such defence being used in the Judgement analysis was noted. However, in 25 of the 38 judgements (those actually pertaining to rape) and in 14 out of the 21 (perceived false rape cases) there was a reference about the medical evidence by the court. In five of the 21 false rape charges, no signs of sexual assault noted in the medicolegal report helped the judge to conclude that sexual contact (if any) was consensual. Quoted below are two excerpts of judgements of the case analysed in this study.

In X (Assumed Name) V. State \& Anr. [15] the court said "There was no corroborating evidence to lend credence to the victim's statement. FSL report did not indicate the respondent's involvement in the crime. Nothing has come on record if any time, the prosecutrix had offered resistance or had suffered any injury on her body to infer forcible rape; she never got herself medically examine" (Emphasis supplied)

In another case of Ranjeet V. The State (NCT of Delhi) [16] the High court said "As per the MLC of the prosecutrix, there was no bite mark on the cheek of the prosecutrix, rather there was a bruise and swelling on her right cheek. There is difference between a bite mark and bruise mark" (Emphasis supplied)

The Delhi High Court judge in the case of State (NCT of Delhi) Vs Kamruddin Alam [17], said that no women would file a charge of sexual molestation only to falsely implicate the accused. Therefore when the circumstances appearing on record of the case disclose that the prosecutrix does not have a strong motive to falsely involve the person charged, the Court should ordinarily have no hesitation in accepting her evidence.

Here, we found that delay in reporting was a common defence used to discredit the victim. However the judges seemed to be sensitive to a victim's situation, showing understanding and empathy to 'the social pressure and the stigma attached to the crime' and the 'circumstances in which the victim is under fear or in trauma'. In the case of Jaishree Vs the State (NCT of Delhi) [18] the judge has laid down emphasis on delay in reporting of FIR.

The law on delay in filing of FIR was clarified by the Supreme Court in the case of Mehraj Singh vs. State of U.P. [19], wherein the court held that FIR in a criminal case is a vital and valuable piece of evidence. Delay in lodging the FIR often results in embellishment, which is a creature of an afterthought. When there is a delay, the FIR gets bereft of the advantage of spontaneity, danger also creeps in of the introduction of a coloured version or exaggerated story

In another case, the Court while hearing a Criminal appeal filled by Mukesh [20], one of the convicts of the Nirbhaya rape case said Delay in lodging of complaint in court or FIR at police station is normally viewed by courts with suspicion because there is possibility of concoction of evidence against an accused. Therefore, it becomes necessary for the prosecution to satisfactorily explain the delay. However Even a long delay can be condoned if the informant has no motive for implicating the accused

In another one of a recently supreme court judgement in the case of P. Rajagopal \& Ors. Etc. vs. State of Tamil Nadu [21], while placing reliance on Mukesh's Judgement [20] said if the delay is satisfactorily explained, the Court will decide the matter on merits without giving much importance to such delay. The Court is duty bound to determine whether the explanation afforded is plausible enough given the facts and circumstances of the case.

In a previous study [5] it was stressed that the process followed by police under Code of Criminal Procedures leads to inevitable contradictions and discrepancies. Discrepancies in the statements made by the victim although given weightage is seldom the ONLY reason why the rape accuse is acquitted. Often there are more reasons for the court to believe that the accused is not guilty of committing rape

The Supreme Court in the State Of Punjab vs Gurmit Singh \& Ors [22] said 
"In cases involving sexual molestation, supposed considerations which have no material effect on the veracity of the prosecution case or even discrepancies in the statement of the prosecutrix should not, unless the discrepancies are such which are of fatal nature, be allowed to throw out an otherwise reliable prosecution case" From the Figure 3 it can be seen that sometimes rape charge is levied just to increase the magnitude of the actual offence that was committed or due to personal enmity between either the victim and offender or their relatives, false rape charges were framed similar to found in the study which interview judges. One of the judges in their interview said "Pressure from the family was said to lead to a different presentation of the self to maintain dignity and honour in front of the family. The central idea being presented in such cases is that such relationships are consensual and only become labelled as abusive when the parents are on the scene"

The following are two instances in our Judgement analysis where rape allegation was made due to personal animosity. In the case of Ranjeet [16] the Delhi High Court after confirming from three sources (Prosecutrix statement, accused's statement and witnesses' statement) concluded that quarrel used to take place between the accused (Ranjeet) and the victim and the victim was not sexually assaulted by Ranjeet.

In the case of Mahendra Vs State (NCT of Delhi) [23]) the court said "As noted above, the prosecution witnesses have admitted enmity and tutoring. Further there are material improvements from the FIR which was also registered after deliberation. There is no corroboration to the version of the prosecutrix either from medical evidence as the hymen was old ruptured and as per the FSL report the blood on the salwar was not connected to the appellant. In view of the evidence on record, it can be safely held that the prosecution has not proved beyond reasonable doubt that Mahender committed the offence punishable under Section 376 IPC" (Emphasis Supplied)

Immoral character of the female is sometimes used as a defence by the accused. The word like "habituated to sex" are used to a female that might have had previous intercourse. It has been clarified in the explanation 2 of the S. 375 IPC that, for each 'Specific' sexual encounter, the consent has to be obtained separately. The explanation also states that a consent to a previous sexual encounter cannot be considered as implied consent for subsequent sexual encounter. Even if a woman has had previous intercourse, the chances of the present case being that of a sexual assault cannot be dismissed directly. The Indian Evidence act was amended in 2002 (24) which now prohibits the defence lawyer to question the women on her previous sexual acts, her personal life, and other private matters. However, the actual effectiveness of this amendment is questionable because recently in an interview, Advocate AP Singh who represented 3 of the 6 accused in Nirbhaya Rape case did not regret the fact that he his strategy included maligning the deceased victim [25].

The two fingers test helps in determining laxity and the sexual activity of the victim i.e. whether the victim is sexually active or not. In a major victory, The Supreme Court has banned this test on the grounds that it violated right to privacy and dignity [26].

The Conviction rate in 2016 has seen a decline from 2006. There could be various reasons for this. It has been said that eight out of ten rape cases are never reported, either due to shame or the stigma that the society attached with a rape victim [9-11]. Therefore, the cases which are reported might be false. Although it cannot be safely concluded that maximum of cases is false from the high conviction rate. However even senior forensic experts [5] carry this perception that Rape is announced when caught and that Real rape cases are very less as they are not reported because of social pressure or fear. Furthermore, improper investigation leads to less sufficient generation of evidence. If evidence cannot be generated then the guilt of the person to convict him of rape cannot be proved beyond reasonable doubt. In Ram @ Ram Kumar Vs The State (NCT of New Delhi) [27] the High court judge condemned the delay of lodging reporting by the police as well type of investigation conducted by them. The police also diluted the charges against the accused by not filling the case under IPC S. 376 (Rape) but rather under IPC S. 511 read with S. 367 (Attempt to commit rape). The court also acknowledged the fact that since the prosecutrix and other family members belonged to poor strata of society and were not so educated, minor discrepancies and inconsistencies in their statements which do not affect the core of the prosecution case are inconsequential. Along with improper filling of police reports, in some instances the Forensic 
reports contained discrepancies as well. In one such case of K V. The State (NCT of Delhi) (28) the judge said that-

"When the first time blood sample of the respondent was sent for DNA finger printing, no DNA could be separated.... It is also not explained how DNA could be separated from the same underwear later on. Further from the evidence led by the prosecution, the safe custody of underwear from 2008 to 2010 when it was sent for DNA Finger Print has also not been proved. Thus the finding of the learned Trial Court that the possibility of tampering of the case property or putrefying of the samples could not be ruled out cannot be faulted with. ..... the respondent being entitled to be acquitted cannot be held to be perverse warranting interference. "(Emphasis Supplied)

Looking at the number of cases pending before the courts from the previous year then one may conclude that judicial proceedings with respect to rape cases is in a sorry state. In 2016, approx. 33000 cases of 2016 which were sent for trail. However about 118000 cases were pending from previous years i.e. 4 times of the cases under trail of year 2016. Only about of $54.4 \%$ of the number of cases from that year alone (18,000 out of 33000 in 2016) are actually concluded. This leaves $(118,000+33,000)-18,000$ cases pending at the end of $2016(134,000$ cases $)$.

The pendency percentage is about 87.6 percentage $[134,000 /(118,000+33,0000]$. This leads to delay in getting justice in a rape case. From the above case we can also infer that delay in the court proceedings can lead to a person being acquitted of the crime he committed because the possibility of tampering of evidence cannot be ruled out

\section{Conclusion}

The Conviction rate, unfortunately has remained stagnated over the years while the number of cases keep on increasing. I conclude that there are case where false rape allegations are made. For each case there were multiple reasons why the case was probably a false allegation.

Relative evidentiary value of Female's testimony and Corroborative evidence: The Delhi HC while placing reliance on the various Supreme Court Judgements regarding presumption of consent and concluded that "broad principle that the prosecution has to prove its case beyond reasonable doubt applies equally to a case of rape" [14]. From the analysis of the common defences used by the advocate of the accused I conclude that the judges sometimes don't accept the prosecutrix statement when there are vital infirmities in them and looks for independent corroboration by medical and police investigation.

The detrimental effect of false rape allegations on the society: Just like a rape victim faces shame and stigma in the society, the rape accused could also faces some stigma. Although I don't intend to imply that one is to be put above the other or they should be compared with each other. Instead I mean to say that an alleged rape offender is also defamed after a false rape case is filled against him. Therefore, due weightage needs to be put on the false rape charges as well. In Raju v. State of Madhya Pradesh [29], the Supreme Court stated that

"It cannot be lost sight of that rape causes the greatest distress and humiliation to the victim but at the same time a false allegation of rape can cause equal distress, humiliation and damage to the accused as well.." (Emphasis added)

\section{Future Scope}

Since 2009, victims of any crime have been given the right to lodge an appeal against acquittal of the accused [30] but because of the low number of victim appeals in this study, a study to explore the nature, extent and outcome of such appeals would be useful.

As far as the precedents set by the Supreme Court while dealing with a case sexual molestation is considered, most of the recommendations are followed. For example, the name of the prosecutrix is to hidden [22, 31], and the court relies on the sole testimony of the prosecutrix when the testimony is sufficient so as to arise the confidence in the court and medical evidences are corroborated when necessary [32]. The recommendation that was not followed was 'Whenever possible female judges tries a case of sexual molestation' made by Supreme Court in case of Gurmit Singh (20) and as mandated by the Section 26(a)(iii) of the Code of Criminal Procedure, 1973 [33]. 


\section{Limitations}

Firstly, the notion whether or not the case is false is based on the authors' personal review of the judgement. It could happen that the case was of a true rape case but the accused was acquitted. In future an analysis of only the cases which are tagged false by court could be done to have a better understanding about false rape cases.

Secondly, only Delhi high court judgments were analysed due to ease in accessing the court judgments. In a future study, Supreme Court or other high court judgments could be analysed. A word of caution is worth mention. The findings of this study may not be generalizable within or outside India however dome of my findings from judgement analysis did actually resembled the NCRB report. Studies conducted under a similar premise will help strengthen the understanding of so called 'False rape allegations'

\section{REFERENCES}

1. S. 376, The Indian Penal Code, 1860.

2. Criminal Law (Amendment) Bill, 2013 (passed by Rajya Sabha on 21/03/2013)

3. Wire.in [Internet], India, ' Conviction Rate for Crimes Against Women Hits Record Low' 2017 Dec 14 [Cited 2020 July 1] Available from- https://thewire.in/gender/conviction-rate-crimeswomen-hits-record-low

4. Crime in India 2018, New Delhi, Director National Crime Records Bureau, Ministry of Home Affairs, Government of India, 2020 Jan. 1311p

5. Barn R, Kumari V, Understanding Complainant Credibility in Rape Appeals: A Case Study of High Court Judgments and Judges' Perspectives in India, Br. J. Criminol 2015;5(3):435-53.

6. Crime in India 2016, New Delhi, National Crime Records Bureau, Ministry of Home Affairs, Government of India, 2017 Nov. 742p

7. Prosecutrix | Definition of Prosecutrix by Oxford Dictionary on Lexico.com also meaning of Prosecutrix [Internet]. Lexico Dictionaries | English. 2020 [cited 2020 Aug 18]. Available from: https://www.lexico.com/definition/prosecutrix

8. Black H, Garner B. Black's law dictionary. 8th ed. Thomson Reuters West; 2004. p. 3728.

9. Prasad S. Medicolegal response to violence against women in India. Viol against Women 1999; 5(5):478-506.

10. Logan TK, Evans L, Stevenson E, Jordan CE. Barriers to services for rural and urban survivors of rape. J Interpers Viol 2005;20(5):591-616.

11. Weiss KG. 'Too Ashamed to Report: Deconstructing the Shame of Sexual Victimization', Fem Criminol 2010;5(3):286-310.

12. Abbas Ahmed Choudhury v. State of Assam, (2010) 12 SCC 115

13. Sadashiv Ramrao Hadbe vs. State of Maharashtra \& Anr. (2006) 10 SCC 92

14. Shiv Pujan@ Shubh Karan Vs The State (NCT Of Delhi), (2017) 237 DLT 512

15. X (Assumed Name) v State \& Anr., Criminal Leave Petition no. 251/2016 (Delhi High Court, $27 / 03 / 2017)$

16. Ranjeet V. The State (NCT of Delhi), 2017 SCC OnLine Del 8053

17. State (NCT of Delhi) Vs Kamruddin Alam, (2017) 2 DLT (Cri) 950

18. Jaishree Vs the State (NCT Of Delhi), 2015 SCC OnLine Del 13649

19. Mehraj Singh vs. State of U.P., 1994 SCC (5) 188

20. Mukesh v. State (NCT of Delhi), (2017) 6 SCC 1

21. P. Rajagopal \& Ors. Etc. Vs. State of Tamil Nadu, (2019) 5 SCC 403

22. The State Of Punjab vs Gurmit Singh \& Ors, 1996 AIR 1393

23. Mahendra Vs State (NCT of Delhi), (2018) 251 DLT 146

24. S. 2, Indian Evidence (Amendment) Act, 2002

25. news18.org [Internet], India, AP Singh, the Lawyer Whose Defence of Nirbhaya Rapists Began With 'Would Have Burnt my Daughter If...' 2020 Feb 10 [Cited 2020 July 1] Available fromhttps://www.news18.com/news/india/ap-singh-the-lawyer-whose-defence-of-nirbhaya-rapistsbegan-with-would-have-burnt-my-daughter-if-2494747.html

26. Lillu@ Rajesh \& Anr vs State Of Haryana, (2013) 14 SCC 643

27. Ram@Ram Kumar Vs The State (NCT Of New Delhi), 2017 SCC OnLine Del 8423

28. K vs THE STATE (NCT OF NEW DELHI), (2017) 2 DLT (Cri) 661

29. Raju v. State of Madhya Pradesh, (2008) 15 SCC 133

30. S. 29, Code of Criminal Procedure (Amendment) Act 2008 
31. Delhi Domestic Working Women's Forum Vs. Union of India and Others, 1995 SCC (1) 14

32. Narender Kumar Vs. State (NCT of Delhi) , (2012) 7 SCC 171

33. S. 4, Code of Criminal Procedure (Amendment) Act 2008

Acknowledgements: Nil

Funding: Nil

Conflict of interest: Nil 